\title{
New species of the genus Carpelimus Leach, 1819 from Central China (Coleoptera: Staphylinidae: Oxytelinae)
}

\section{Новый вид рода Carpelimus Leach, 1819 из Џентрального Китая (Coleoptera: Staphylinidae: Oxytelinae)}

\author{
M.Yu. Gildenkov \\ М.Ю. Гильденков
}

Smolensk State University, Przhevalsky str. 4, Smolensk 214000, Russia. E-mail: mgildenkov@mail.ru Смоленский государственный университет, Пржевальского 4, Смоленск 214000, Россия

\begin{abstract}
KEY WORDS: Coleoptera, Staphylinidae, Carpelimus, new species, Palaearctic region, China. КЛЮЧЕВЫЕ СЛОВА: Coleoptera, Staphylinidae, Carpelimus, новый вид, Палеарктика, Китай.
\end{abstract}

ABSTRACT: The new species Carpelimus (s.str.) sichuanensis sp.n. is described from the Palaearctic region of China.

РЕЗЮМЕ: Описывается новый вид Carpelimus (s.str.) sichuanensis sp.n. из палеарктической части Китая.

The subgenus Carpelimus Leach, 1819 is a monophyletic group with a characteristic internal sac of the aedeagus that always bears strongly sclerotised tooth-like structures [Gildenkov, 2001a, b; 2003; 2007a, b]. This subgenus is one of the best known in the genus Carpelimus, and the discovery of a new species, especially in the Palaearctic region, is therefore of considerable interest. Forty five species and 3 non-nominative subspecies of the genus Carpelimus have so far been described from the Old World [Gildenkov, 2015b], of which 16 species from China and Taiwan [Gildenkov, 2015a, b; 2016]. For the Palaearctic part of China [Gildenkov, 2016], only 7 species Carpelimus (s.str.) are currently known: $C$. capillus Gildenkov, 2013; C. indicus (Kraatz, 1859); C. politus politus (Kiesenwetter, 1844); C. praelongus (Bernhauer, 1938); C. pusillus (Gravenhorst, 1802); C. tener (Bernhauer, 1902); C. vagus (Sharp, 1889). Of those, only 4 species (C. indicus, C. politus politus, C. pusillus, and $C$. tener) have so far been reported from Sichuan province, from which the new species is described and which is regarded here as part of the Palaearctic region [Gildenkov, 2015a; 2016].

This paper is based on the specimens deposited in the following collections: cGR — private collection of Guillaume de Rougemont (Oxford, Great Britain); cMG private collection of M. Gildenkov (Smolensk, Russia).

In the present study, standard methods were used for the taxonomic research of insects; the preparations were made on an MBS-10 binocular microscope. The genital preparations were processed using $10 \% \mathrm{KOH}$ and then fixed in euparal. In the descriptions and diagnoses giving the length to width ratio for the head, pronotum, and elytra, the following standard units were used: 7 standard units = $0.1 \mathrm{~mm}$; thus, 1 standard unit constitutes about $0.0143 \mathrm{~mm}$.

\section{Carpelimus (s.str.) sichuanensis Gildenkov, sp.n.} Figs 1-2.

MATERIAL. Holotype, O' "CHINA X.1985 Sichuan: Leshan | G. de Rougemont" (cGR). Paratypes: 1 i "CHINA X.1985 Sichuan: Leshan | G. de Rougemont" (cGR); O' "CHINA: N-Sichuan (Daba Shan), $65 \mathrm{~km} \mathrm{~N}$ Fengiie, river bank, $1000 \mathrm{~m}, 31^{\circ} 40^{\prime} \mathrm{N}, 109^{\circ} 34^{\prime} \mathrm{E}$, leg. M. Schülke [C01-08]" "10.VII.2001, fine gravel bank (floating, treading) [C01-08]" (cMG).

DESCRIPTION Male (holotype). Length $2.4 \mathrm{~mm}$. Colouration brown, integument slightly shining. Head and abdomen black brown; pronotum and elytra dark brown with slight reddish tint, much paler than head and abdomen; legs yellowish brown; antennal base light brown, progressively darker to brown at apex. Body with short, light-coloured setae.

Head transverse, with wide base, ratio of head length (from neck mid-length to anterior margin of clypeus) to its maximum width about 20:30. Neck constriction prominent. Eyes large, convex, occupying almost entire lateral side of head; temples almost indistinct, head widest across eyes (Fig 1). Head surface with delicate, fine and dense punctation. Diameter of punctures on vertex more than 5 times as small as that of eye facet. Punctures on front smaller and more densely set. Punctures on vertex separated by slightly less than their diameter, interspaces smooth and slightly shining. Antennae long. Antennal segment 1 elongate, cylindrical, more than twice as long as its maximum width; segment 2 conical, more than twice as long as its maximum width, much narrower and shorter than segment 1 ; segment 3 conical, more than twice as long as its maximum width, much narrower and shorter than segment 2 ; segments 4-7 similar, with lengths exceeding significantly maximum widths; segment 8 conical, about as long as wide; segments 9-10 slightly conical, about as long as wide, much more massive than segment 8 ; segment 11 massive, pointed apically, about 1.5 times as long as its maximum width; last 3 segments form loose club.

Pronotum widened from base, with maximum width about $2 / 3$ its length from base, then progressively narrowed. Lateral margin shallowly emarginate from base, broadly rounded from its maximum width (Fig. 1). Ratio of pronotum length to its maximum width about 27:33. Surface of pronotum with delicate, fine and dense punctation; punctures separated by distance equal to or slightly less than their diameter, interspaces smooth and slightly shining. Punctation similar to that on vertex. Base of pronotal disc with prominent, symmetrical, widely-crescent depressions. Central part of disc with shallower, oval depressions merging across midline to single butterfly-shaped depression (Fig. 1). 

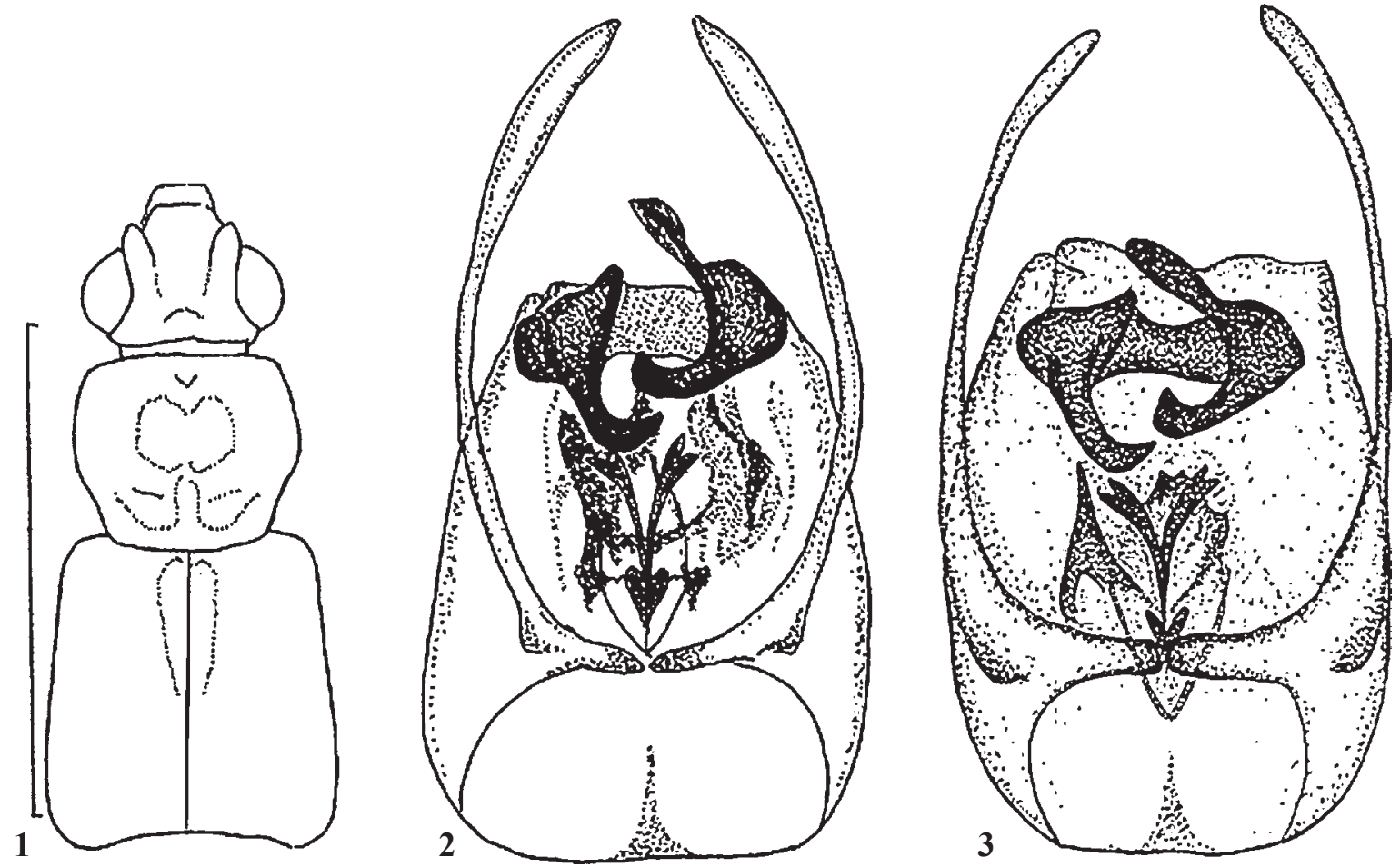

Figs 1-3. Carpelimus (s.str.) spp: 1-2 - C. sichuanensis Gildenkov, sp.n.; $3-$ C. politus politus (Kiesenwetter, 1844); $1-$ outline of head, pronotum and elytra; $2-3-$ aedeagus, ventral view. Scale bars: $1-1 \mathrm{~mm} ; 2-3-0.25 \mathrm{~mm}$.

Рис. 1-3. Carpelimus (s.str.) spp: 1-2 - C. sichuanensis Gildenkov, sp.n.; 3 - C. politus politus (Kiesenwetter, 1844); 1 - контур головы, передненспинки и надкрылий; 2-3 - эдеагус, вентрально. Масштаб: $1-1$ мм; 2-3 - 0,25 мм.

Elytra: Ratio of length of elytra to their combined width about 43:43. Surface of elytra with 2 shallow longitudinal depressions extending from scutellum along suture to slightly beyond mid-length of elytra (Fig. 1). Elytra with rather distinct, fine and dense punctation. Diameter of punctures about 2.5 times as small as that of eye facet, much larger than diameters of those on pronotum and head. Punctures separated by distance equal to or slightly less than their diameter, interspaces smooth and slightly shining.

Abdomen with very delicate, fine and dense punctation.

Aedeagus of characteristic structure (Fig. 2).

Female. Sexual dimorphism absent, female similar to male. Spermatheca typical in structure for subgenus [Gildenkov, 2003; 2015b].

COMPARATIVE REMARKS. This species is very similar in its coloration, body dimensions, punctation patterns and the shape of the pronotum to closely related and cohabiting $C$. politus politus and C. tener. The new species is clearly distinguishable from those only by the structure of its aedeagus. It is most similar to $C$. politus politus in the shape of the sclerotised denticles in the internal sac of the aedeagus (Fig. 3 ), but can be easily differentiated from the latter by the shape of the sclerites at the base of the sac (Fig. 2).

DISTRIBUTION. China: Sichuan.

ETYMOLOGY. Named for its geographical distribution.

ACKNOWLEDGEMENTS. The author wishes to thank Guillaume de Rougemont (Oxford) and Michael Schülke (Berlin), who kindly provided the material for this study. The study was performed within the framework of the basic part of the State task of the Smolensk State University for 2017-2019.

\section{References}

Gildenkov M.Yu. 2001a. [The fauna of Carpelimus of the Palaearctic (Coleoptera, Staphylinidae). Problems of species and speciation. Part 1. The history of research. Morpho-ecological features. System of the genus. Description of species]. Smolensk: SGPU. 304 pp. [in Russian].

Gildenkov M.Yu. 2001b. [The fauna of Carpelimus of the Palaearctic (Coleoptera, Staphylinidae). Problems of species and speciation. Part 2. Keys to species. The phylogenetic relations in genus. Problems of species and speciation]. Smolensk: SGPU. 176 pp. [in Russian].

Gildenkov M. Yu. 2003. Classification of the Genus Carpelimus (Coleoptera, Staphylinidae) within the Palaearctic Region: 2. Keys to Species of the Subgenera Carpelimus, Paratrogophloeus, Myopinus, and Bucephalinus // Entomological Review. Vol.83. No.1. P.69-81.

Gildenkov M.Yu. 2007a. [A review of the subgenus Carpelimus s.str. (Coleoptera, Staphylinidae) from tropical Africa] // Zoologicheskii Zhurnal. Vol.86. No.9. P.1073-1085 [in Russian, with English summary].

Gildenkov M.Yu. 2007b. A Review of the Subgenus Carpelimus s.str. (Coleoptera, Staphylinidae) from tropical Africa // Entomological Review. Vol.87. No7. P.893-907.

Gildenkov M.Yu. 2015a. New records of the genus Carpelimus Leach, 1819 (Coleoptera: Staphylinidae: Oxytelinae) from Taiwan // Acta Biologica Universitatis Daugavpiliensis. Vol.15. No.2. P.395-405.

Gildenkov, M.Yu. 2015b. [Fauna of Carpelimus of the Old World (Coleoptera: Staphylinidae)]. Smolensk: SmolSU. 414 pp. [in Russian, with English summary].

Gildenkov M.Yu. 2016. New records of the species of Carpelimus Leach, 1819 (Coleoptera: Staphylinidae, Oxytelinae) from China // Far Eastern Entomologist. No.320. P.27-32. 